\title{
Transformasi Fungsi Komunikator dan Fungsi Konstruksi Akun Facebook Presiden SBY
}

\author{
F. X. Lilik Dwi Mardjianto \\ Universitas Multimedia Nusantara \\ Jl. Scientia Boulevard, Gading Serpong, Tangerang, Banten 15811 \\ Email: 1ilikdwi@yahoo.com, lilik@umn.ac.id
}

\begin{abstract}
New media in a form of social media has grown rapidly nowadays. The growth of social media is supported by technological advances connected people around the world. They are connected to each other and easily exchange messages. The transformation has finally weakened the media itself. This is a concept paper combining two methodoloies, namely literature review and content analysis of Presiden Yudhoyono's Facebook account. This paper reveals that public connectedness within digital era has brought back the media to its original function; media that has only message distribution function, without having message construction function.
\end{abstract}

Keywords: new media, reality construction, social media, transformation.

\begin{abstract}
Abstrak: Media baru dalam bentuk media sosial berkembang begitu pesat. Perkembangan yang didukung dengan kemajuan teknologi tersebut telah menciptakan keterhubungan antar orang. Publik terhubung satu dengan yang lain dan saling bertukar pesan. Transformasi peran dan fungsi audiens akibat kemunculan media sosial itu berpotensi mendegradasi fungsi media. Makalah ini adalah makalah konseptual yang menggabungkan dua metodologi, yaitu studi pustaka dan analisis isi sederhana terhadap akun Facebook Presiden Susilo Bambang Yudhoyono. Makalah ini mengungkap bahwa keterhubungan publik di era digital adalah masa ketika media kembali kepada fungsi awalnya, hanya sebagai perantara distribusi pesan, tanpa lagi dilengkapi kemampuan untuk mengemas atau mengonstruksi makna.
\end{abstract}

Kata Kunci: konstruksi realitas, media baru, media sosial, transformasi

Perkembangan media baru merupakan fenomena yang sangat dominan. Perkembangan tersebut tidak bisa dilepaskan dari kemajuan teknologi yang mendekati sebuah keniscayaan. Bahkan, Neil Postman menegaskan bahwa perkembangan teknologi adalah hal yang tidak bisa dihindari. Fenomena itu adalah salah satu kepastian dari sekian banyak ketidakpastian di muka bumi (Postman, 1993, h. 55). Media baru sering dipertentangkan dengan media konvensional. Salah satu yang membedakan keduanya adalah interaktivitas. Media baru, dengan dukungan internet, menjadi media yang sangat interaktif. Semua pihak yang terlibat di dalam proses komunikasi melalui media baru seakan melakukan komunikasi yang berlangsung tanpa kendala waktu. Semua pesan yang termuat bisa langsung ditanggapi saat itu juga. Interaktivitas itu menjadi salah satu daya tarik utama media baru. Kondisi tersebut membuat setiap pengguna media baru bisa mengunggah informasi apapun. Dengan demikian, media baru menjadi media alternatif tempat orang menemukan informasi yang tidak bisa 
ditemukan di media konvensional (Sharma, 2007, h. 43). Maka, tidak mengherankan jika Shoemaker dan Reese menganalogikan media baru dan internet sebagai jalan raya tempat segala informasi melintas (1996, h. 217). Sementara itu, media konvensional, seperti surat kabar dan televisi, tidak terlalu bersifat langsung. Audiens tidak bisa langsung memberikan umpan balik mengenai isi yang termuat di dalam media konvensional. Mereka memerlukan rentang waktu tertentu untuk menyuarakan umpan balik tersebut.

Fenomena perubahan platform media memberikan ruang perubahan dibidang lain. Berbagai aspek, termasuk pola komunikasi massa, mengalami transformasi. Bahkan, jurnalisme pun mengalami proses transformasi. Jurnalisme di era media baru mengadopsi unsur interaktivitas. Beberapa media bahkan memberdayakan publik sebagai kontributor informasi dalam wadah jurnalisme warga.

Salah satu fungsi media, bukan hanya media yang melakukan kegiatan jurnalistik, adalah mengemas pesan. Pesan tersebut dikemas dengan cara tertentu sehingga bisa dimaknai oleh audiens secara tertentu pula. Proses pengemasan pesan itu melibatkan banyak fungsi dan kepentingan, sehingga beberapa kalangan menyatakan bahwa apa yang telah dikemas oleh media sangat mungkin tidak sesuai-atau bahkan bertolak belakang-dengan kenyataan. Pada fase tertentu, konten media bukanlah imitasi dari realitas, tapi hasil konstruksi yang menghasilkan realitas baru. Konten media bukan salinan dari realitas, tapi konstruksi realitas (Eriyanto, 2001). Kontruksi sosial atas realitas ini tidak harus selalu dimaknai secara negatif. Konstruksi realitas yang dilakukan demi kepentingan publik sangat mungkin terwujud dalam fungsi media yang lain, yaitu fungsi pengawasan. Watchdog, terminologi yang merujuk pada fungsi tersebut, muncul ketika media menggunakan "otoritas" dalam mengonstruksi pesan untuk mengawasi penguasa dan memperjuangkan kepentingan publik.

Media sosial sebagai salah satu bagian dari media baru muncul seiring dengan perkembangan teknologi. Publik sangat dimungkinkan untuk terlibat aktif sebagai kreator konten di dalam media sosial. Kehadiran media sosial seakan menjadi jawaban terhadap dahaga publik untuk terhubung satu sama lain. Keterhubungan itu berimplikasi pada penumpukan pesan hasil karya publik di media sosial. Hal ini tentunya memungkinkan munculnya pertanyaan besar apakah peran publik atau pengguna media yang sangat besar dalam mengemas pesan di era media baru itu akan mentransformasi atau bahkan menghilangkan fungsi konstruksi yang dimiliki media.

Keterlibatan publik di dalam media sosial sudah tak terbendung lagi. Sebagian besar orang-pejabat maupun bukan pejabat - menjadi anggota "keluarga besar" media sosial. Presiden Susilo Bambang Yudhoyono (SBY) adalah tokoh publik yang masuk dalam kategori itu, terlebih setelah dia dan tim kepresidenan aktif di dalam Facebook. Akun Facebook ini 
dikelola oleh SBY dan tim kepresidenan. Publik bisa membaca sejumlah pemikiran dalam bentuk narasi kata-kata yang diunggah oleh SBY sendiri. Selain itu, kutipan dari berbagai pidato serta foto-foto kegiatan SBY juga ada di akun tersebut.

Foto-foto yang diunggah melalui akun tersebut menunjukkan kegiatan SBY di dalam berbagai situasi. SBY kadang tampil formal, namun juga sering terlihat berada dalam suasana santai. Profil "santai" SBY menjadi hal yang menarik dan sekaligus membedakan dengan apa yang publik sering lihat di media konvensional. Hal itu seperti "panggung belakang" para tokoh publik yang selama ini sengaja disembunyikan, dan akhirnya tersibak di era media baru. Pada saat yang sama, media sosial seakan menjadi "milik" publik atau para penggunanya. Segala yang publik ingin unggah, akan terunggah. Segala yang SBY ingin perlihatkan akan terlihat. Hal itu menimbulkan pertanyaan apakah media sosial tidak memiliki fungsi konstruksi realitas (sebuah fungsi yang sering diterapkan oleh media tradisional). Kedua hal tersebut, yaitu transformasi fungsi komunikator dan fungsi konstruksi realitas, adalah dua hal yang akan diulas di dalam artikel ini.

Artikel ini adalah artikel konseptual, sehingga menggunakan metode studi pustaka guna mendukung konseptualisasi gagasan. Selain itu, artikel ini juga memaparkan hasil analisis terhadap isi akun Facebook Presiden SBY. Analisis ini bersifat deskriptif dan sederhana. Hasil analisis isi tersebut bisa berfungsi sebagai bukti atau contoh untuk memperkuat konseptualisasi gagasan yang ditawarkan oleh penulis.

\section{Konstruksi Realitas dan Framing}

Peter L. Berger dan Thomas Luckmann menyatakan, realitas dikonstruksi atau diciptakan secara sosial (1966, h. 13). Dalam buku berjudul The Social Construction of Reality: A Treatise in the Sociological of Knowledge, para sosiolog tersebut mengungkapkan bahwa karakteristik masyarakat yang terlibat di dalam proses interaksi sosial akan dengan sendirinya menciptakan makna bersama.

Manusia, dengan bekal sosial dan pengetahuan mereka, sangat mungkin memiliki pemahaman yang beragam tentang suatu hal. Eriyanto berusaha menafsirkan pemikiran Berger dan Luckman bahwa pengalaman, pendidikan, kecenderungan, dan pergaulan sosial yang dialami oleh setiap individu sangat memungkinkan bagi individu tersebut untuk menafsirkan sebuah kenyataan secara berbeda dengan individu yang lain (Eriyanto, 2001, h. 15-16).

Media massa sebagai kumpulan sejumlah individu juga melakukan hal yang sama. Pengalaman sosial yang unik dari setiap individu yang berada di dalamnya membuat media menjadi suatu entitas yang tidak pasif. Media menjadi representasi masyarakat yang memiliki sikap terhadap sesuatu. Media secara umum memiliki kecenderungan untuk menampilkan "realitas" yang telah mereka kemas dengan cara dan kepentingan tertentu. Oleh karena itu, tidak berlebihan jika beberapa kalangan menganggap "realitas" yang ditampilkan di 
media bisa jadi berbeda dengan kenyataan yang sebenarnya.

Proses pengemasan realitas ini bisa dianalisis menggunakan metode analisis framing. Metode analisis ini sering digunakan untuk menganalisis isi media yang melakukan kegiatan jurnalistik. Analisis framing secara sederhana bisa diartikan sebagai cara menampilkan pesan atau realitas di dalam media massa dengan cara yang khas sehingga bagian tertentu akan terlihat jelas dan bagian yang lain tidak jelas. Layaknya sebuah bingkai atau jendela, framing memungkinkan audiens melihat sebagian dari realitas secara jelas, namun bagian yang tidak masuk di dalam bingkai atau jendela akan terlihat suram atau bahkan mungkin tidak terlihat (Eriyanto, 2001, h. 3-4). Secara singkat, analisis framing akan memperlihatkan bagaimana media menonjolkan sebuah fakta dan mengaburkan fakta lain sesuai dengan kepentingan media tersebut. Hal yang sama juga ditegaskan oleh Entman bahwa membingkai sebuah realitas adalah menyeleksi bagian dari realitas dan menampilkannya di dalam isi media untuk memperlihatkan permasalahan, penyebab, pertimbangan moral, dan penyelesaian dari masalah tersebut. Membingkai sebuah peristiwa, pesan, atau kenyataan dilakukan dengan menyeleksi, memberikan penekanan, bahkan penghilangan fakta sehingga tercipta kesan atau makna tertentu di dalam isi media (Weaver, McCombs, dan Shaw, 2004, h. 263).

Praktik penonjolan sebagian dari realitas dan pengaburan realitas yang lain tidak hanya dilakukan oleh media yang melakukan kegiatan jurnalistik. Media dalampengertianumumjugamelakukannya, misalnya berbagai konten di televisi hadir di hadapan pemirsa setelah melalui proses pematangan oleh tim produksi. Melalui proses di dalam tim produksi inilah sebuah realitas dikemas. Fenomena ini menjadi dasar untuk menegaskan bahwa media adalah sebuah entitas yang aktif. Dia hidup di dalam paradigma konstruktivis, yaitu sebagai paradigma yang menganggap media mampu mengemas dan menciptakan realitas tertentu, bukan hanya sekedar saluran informasi.

\section{Transformasi Komunikator}

Perkembangan media baru membuka ruang bagi publik dalam proses komunikasi. Publik yang hanya berstatus sebagai "receiver" dalam pola komunikasi linier, kini bertransformasi sebagai entitas yang menjalankan fungsi produksi pesan. Tradisi riset behavioral menunjukkan transformasi publik tersebut. Transformasi itu berjalan beriringan dengan perkembangan platform media massa. Tradisi riset behavioral memiliki dua sudut pandang terhadap publik, yaitu publik pasif dan publik aktif (McQuail, 2005). Tradisi ini percaya bahwa pada masa tertentu, publik tampil sebagai sebuah komunitas pasif yang hanya menerima pesan. Pada tahap ini, publik sangat bergantung pada pesan yang dikemas oleh media. Dengan kata lain, media memiliki otoritas yang luar biasa besar untuk mengemas pesan yang akan disampaikan kepada publik. Sudut pandang lainnya menganggap publik sebagai sebuah 
kelompok yang aktif. Mereka memiliki cara mereka sendiri dalam memaknai sesuatu. Oleh karena itu, mereka tidak sepenuhnya bersandar pada otoritas media. Bahkan, dalam kasus tertentu, publik justru menjadi produsen pesan. Kasus tertentu yang dimaksud adalah transformasi publik dan media di era digital.

Facebook adalah salah satu bentuk atau varian dari media yang muncul di era digital. Sebagai sebuah jejaring, Facebook masuk di dalam kategori media sosial. Publik memiliki ruang ekspresi di dalam aplikasi tersebut. Mereka bebas untuk terhubung dengan siapapun. Mereka juga bebas untuk mengemas serta mendistribusikan pesan apapun. Karakteristik sebagai sebuah jejaring sosial yang terbuka itu membuat Facebook sangat diminati, bahkan oleh para figur publik, termasuk Presiden Susilo Bambang Yudhoyono (SBY).

Presiden SBY bergabung di Facebook sejak 5 Juli 2013. Dia meluncurkan akun tersebut di Istana Bogor dan diliput oleh sejumlah wartawan (Kompas.com, 2013). Halaman muka akun tersebut memuat tanda khusus yang disematkan oleh pengelola Facebook untuk menegaskan bahwa akun itu adalah akun resmi SBY. Tanda yang sama juga disematkan kepada akun-akun milik tokoh publik lainnya. Halaman muka akun SBY juga menyajikan pernyataan bahwa akun tersebut dikelola langsung oleh SBY dan sebuah tim khusus. Merujuk pada pola dan unsur komunikasi, SBY dan timnya masuk di dalam kategori komunikator. Akun Facebook SBY berisi berbagai materi, mulai dari foto sampai sejumlah kutipan tentang berbagai topik. Makalah ini secara khusus membahas materi berupa foto yang menampilkan sosok SBY.

Selama dua bulan sejak peluncuran, SBY dan tim telah mengunggah 135 foto yang menampilkan sosok SBY dan keluarganya. Sebagian besar foto tersebut menggambarkan aktivitas formal SBY sebagai presiden. Penampilan seseorang dalam sebuah foto bisa dianalisis dengan konsep dramaturgy. Konsep ini menyatakan bahwa seseorang akan menampilkan diri layaknya aktor yang sedang memerankan peran tertentu di atas panggung drama. Dia akan tampil sebaik mungkin karena dirinya sadar sedang menjadi pusat perhatian penonton. Namun, sebelum atau sesudah tampil, dia akan berada di balik panggung (backstage). Suasana di balik panggung ini berbeda dengan suasana di panggung depan (front stage). Para aktor yang berada di belakang panggung cenderung untuk tampil apa adanya. Hal itu mereka lakukan karena mereka sadar tidak ada audiens yang akan memperhatikan hal tersebut. Kenneth Burke memperkenalkan konsep dramatistic pentad untuk menganalisis penggunaan simbol dalam sebuah komunikasi. Melalui konsep tersebut, seseorang bisa dianalisis keberadaannya dalam sebuah panggung komunikasi. Burke menyatakan, perilaku seseorang bisa dianalisis menggunakan beberapa elemen di dalam dramatistic pentad, yaitu act (apa yang dilakukan); scene (kapan dan di mana tindakan dilakukan); agent (siapa yang melakukan); agency (cara melakukan); dan purpose 
(tujuan dari tindakan yang dilakukan). peluncuran akun Facebook tersebut. Kategori Kelima elemen tersebut bisa menjawab sosial berisi 72 foto SBY saat berada di lokasi aspek siapa, di mana, kapan, bagaimana dan mengapa sebuah tindakan dilakukan (German, 2009, h. 321).

Penulis menggunakan elemen-elemen dramatistic pentad untuk menganalisis foto-foto SBY dan keluarganya. Berdasarkan analisis tersebut, penulis bisa mengklasifikasikan foto-foto tersebutke dalam beberapa kategori, yaitu sosial, keamanan, politik, ekonomi, dan personal. Sosial menjadi bencana atau melakukan sejumlah aktivitas sosial dan keagamaan. Kategori berikutnya adalah politik yang berisi 25 foto SBY yang sedang menyampaikan pidato politik atau sedang bersama beberapa politisi. Personal, keamanan dan ekonomi adalah tiga kategori yang menempati tiga posisi terendah dalam hal kuantitas foto. Gambar 1. berikut akan memberikan penjelasan distribusi foto ke dalam berbagai kategori.

kategori yang berisi sebagian foto SBY yang diunggah dalam kurun waktu dua bulan sejak

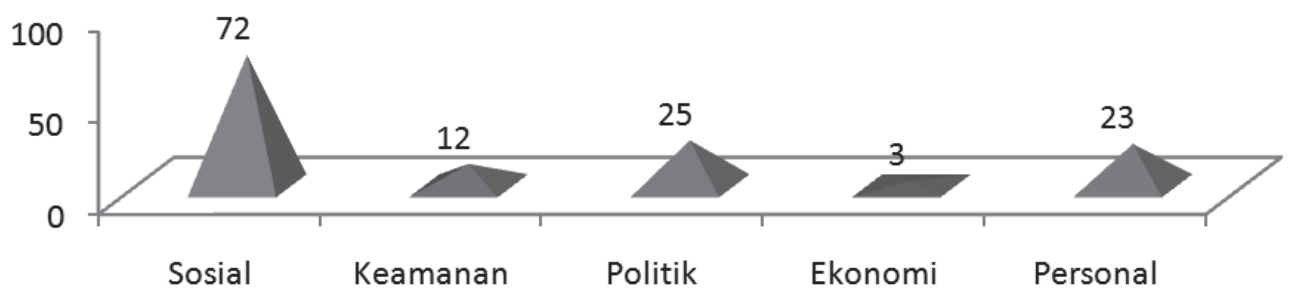

Gambar 1 Grafik Kategorisasi Foto

Kategori sosial, keamanan, politik, dan ekonomi merupakan bagian dari panggung depan SBY. Di area tersebut, SBY ditampilkan sesempurna mungkin. Semua telah diatur sedemikian rupa sehingga SBY bisa tampil sebagai pusat perhatian dengan segala kesempurnaannya. Foto ketika SBY menyalami para pemudik gambar 2 adalah salah satu contoh yang bisa menjelaskan hal tersebut.

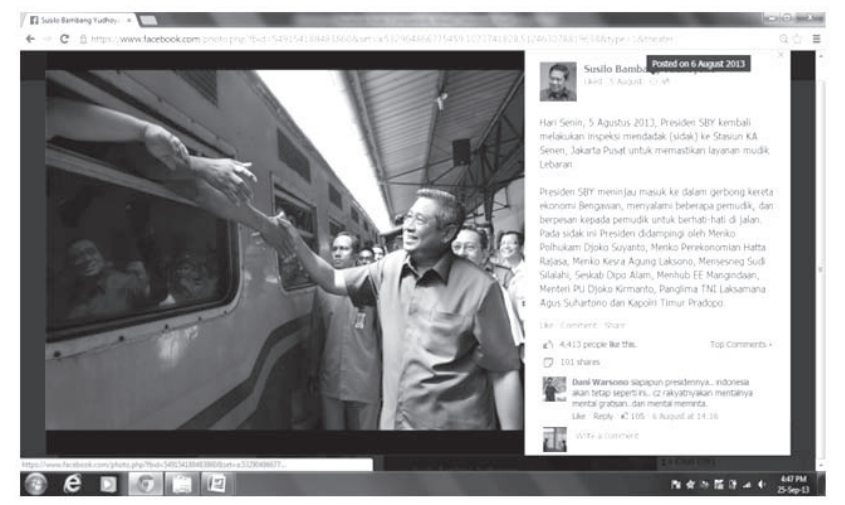

Gambar 2 Foto 1 Inspeksi Arus Mudik 
Selain empat kategori tersebut, masih ada satu kategori lagi, yaitu personal. Kategori personal ini berisi 23 foto yang menggambarkan aktivitas SBY bersama istri, anak, cucu, dan menantu. Fotofoto itu tidak terkait dengan kegiatan kenegaraan. Di dalam foto itu, SBY tampil "casual". Selain itu juga ada beberapa foto yang menggambarkan persiapan SBY dan perangkat kepresidenan untuk melakukan sejumlah kegiatan kenegaraan. Menurut konsep dramaturgy, penampilan di dalam foto-foto itu masuk dalam dimensi backstage.

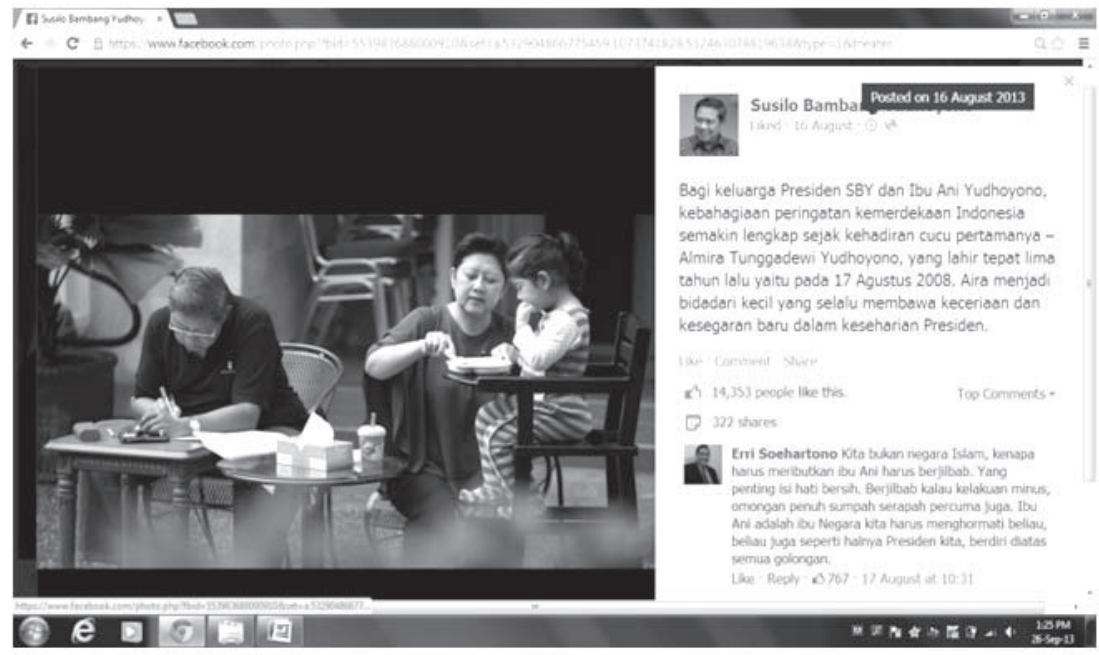

Gambar 3 Foto SBY dan Keluarga

SBY dan figur publik yang lain memiliki sejumlah perangkat yang akan mengemas segala bentuk kegiatan yang akan dijalani. Beberapa kegiatan itu masuk di dalam kategori panggung depan. Hal itu berarti SBY dan tim sadar bahwa aktivitas mereka akan disaksikan oleh publik biasanya setelah disalurkan melalui media massa. Di era media konvensional, publik jarang menyaksikan aktivitas figur publik di area backstage. Pada saat yang sama, media di era konvensional hanya memiliki sedikit akses untuk masuk ke area tersebut. Area itu sengaja ditutup sehingga hanya si figur dan orang terdekatnya saja yang bisa masuk. Erving Goffman menegaskan bahwa ketertutupan area belakang panggung itu adalah sebuah keniscayaan karena di dalamnya terdapat berbagai aktivitas yang mungkin tidak sesempurna penampilan di panggung depan. Layaknya sebuah proses pertunjukan drama, Goffman menyatakan bahwa area belakang adalah tempat bagi para aktor untuk - misalnya-mengganti atau berdebat tentang baju yang akan mereka kenakan di atas panggung depan atau sekedar bersantai tanpa diketahui oleh penonton. Bahkan, menurut Goffman, para aktor bisa menjadi orang yang memiliki sikap, sifat, dan perilaku "asli" yang sangat berbeda dengan apa yang dia tampilkan di depan penonton. Para aktor bisa menanggalkan penokohan mereka ketika berada di area belakang (Goffman, 1956, h. 70).

Transformasi terjadi ketika memasuki era media baru. Media sosial, sebagai salah 
satu platform media baru, menawarkan keterhubungan antar manusia. Kebutuhan manusia untuk berkomunikasi secara personal, cepat, dan melintas batas bertemu dengan kemajuan teknologi yang bisa mewujudkannya. Hal ini pula yang dialami oleh para tokoh publik, termasuk SBY. Area panggung belakang yang tertutup di era media konvensional, kini sengaja dibuka. Para komunikator yang masuk dalam kategori tokoh publik dengan sengaja membuka panggung belakang mereka sehingga segala aktivitas informal mereka bisa disaksikan oleh publik. Media sosial menjadi pilihan mereka untuk membuka diri.

Meski demikian, pandangan kritis bisa menganalisis fenomena ini secara lebih mendalam. Panggung belakang SBY dan tokoh lainnya tidak serta merta runtuh dan hilang ketika ditampilkan kepada publik melalui media sosial. Hal itu bisa jadi mengindikasikan bahwa panggung belakang yang terpublikasi itu hanya sebuah konstruksi yang sengaja ditampilkan untuk kesan tertentu. Foto SBY yang sedang menyiapkan naskah pidato bersama Ibu Negara yang sedang menyuap sang cucu sangat mungkin telah melalui proses pengemasan. Konstruksi itu bisa menimbulkan kesan bahwa SBY adalah seorang presiden yang tetap memperhatikan tugas negara saat di rumah, dan pada saat yang sama bisa menjalankan fungsi sebagai sosok yang sangat mencintai keluarganya. Dengan demikian, yang tadinya menjadi panggung belakang, kini menjadi "panggung belakang yang terkonstruksi" dan siap untuk disebarluaskan. Para politisi, termasuk seorang presiden, akan menampilkan diri sebaik mungkin supaya terlihat bagus di mata audiens. Bahkan, beberapa dari politisi menganggap penampilan fisik adalah faktor utama penunjang kesempurnaan penampilan di depan publik (Newman dan Perloff, 2004). Era digital adalah era ketika komunikator memiliki peran yang sangat strategis untuk mengemas pesan sesuai keinginan mereka, tanpa ada baku. Semua pihak bisa mengunggah pesan tanpa ada standar objektivitas (Thwaites, Lloyd, dan Mules, 2002). Hal ini tentunya menimbulkan pertanyaan bagaimana peran media sosial dalam mengemas pesan.

\section{Transformasi Fungsi Media}

Konektivitas media massa konvensional masih relatif rendah. Hal ini berarti komunikator tidak terhubung secara langsung dengan audiens. Komunikator tidak bisa menyampaikan pesan secara leluasa dan utuh kepada audiens. Pada saat yang sama, audiens tidak bisa merespon pesan itu secara leluasa, utuh, dan seketika. Realitas tentang komunikator akan dikemas ulang oleh media massa, baru kemudian didistribusikan kepada audiens. Oleh karena itu, realitas tentang komunikator sangat mungkin mengalami perubahan, atau bahkan bias, setelah dikemas ulang oleh media. Peran konstruksi pesan ini adalah salah satu peran yang paling menonjol dari media konvensional.

W. Lance Bennett menawarkan sebuah model konstruksi pesan yang biasa dilakukan oleh media massa. Dia mengemas model itu untuk menjelaskan fenomena 
konstruksi realitas yang sering dilakukan oleh pers. Model tersebut memiliki empat level atau gerbang penentu konstruksi pesan, yaitu pertimbangan personal awak media; rutinitas media yang mencakup prosedur birokrasi dan organisasional dalam penumpulan berita atau pesan; faktor ekonomi yang di dalamnya ada pertimbangan tentang efisiensi biaya dan demografi audiens; dan dimensi teknologi yang berpengaruh terhadap format media untuk menarik perhatian audiens (Bennet, 2004, h. 284).

Konsep yang ditawarkan oleh Bennett sangat aplikatif untuk pers di era konvensional. Namun, model tersebut juga aplikatif untuk media pada umumnya yang tidak melakukan kegiatan jurnalistik. Media, menurut model tersebut, akan mengemas pesan berdasarkan pengalaman atau keyakinan dari setiap awak medianya; berdasarkan rutinitas atau kebiasaan media tersebut; berdasarkan ketersediaan atau kebutuhan ekonomi media itu; dan tentu saja berdasarkan kemampuan teknologi yang dimiliki. Sebagai contoh, media partisan yang diisi oleh simpatisan partai tertentu pasti akan mengemas informasi tentang partai lain secara tidak utuh atau bahkan negatif dengan menggunakan platform teknologi yang mereka kuasai demi meraup keuntungan tertentu. Sebagai contoh lain, pembuat film biografi tokoh akan menambahkan atau menghilangkan adegan tertentu dengan menggunakan teknologi tertentu pula untuk mendapatkan sebuah film yang dramatis dan mendatangkan keuntungan.
Fungsi konstruksi pesan inilah yang tidak terdapat di dalam media sosial. Media sosial telah "kehilangan" fungsi konstruksi realitas sosial. Facebook dengan segala fitur yang ada memungkinkan komunikator secara bebas mengemas pesan sesuai dengan keinginan atau kepentingannya. Pada saat yang sama, audiens bisa menangkap pesan tersebut seperti ketika dilepaskan oleh komunikator; tanpa ada distorsi apapun selama melalui media sosial sebagai wahana distribusi. Sebagai contoh kasus, SBY dan tim bisa dengan leluasa mengunggah berbagai foto yang menggambarkan banyak hal. Keleluasaan itu tidak mengalami gangguan sama sekali dari Facebook selaku media sosial. Sebagai media, aplikasi Facebook tidak melakukan proses seleksi, penekanan, pengemasan, atau bahkan penghilangan, realitas tertentu. Singkatnya, Facebook tidak melakukan proses konstruksi makna dan realitas. Pada tahap ini, perkembangan teknologi memengaruhi transformasi fungsi media.

\section{SIMPULAN}

Teknologi adalah faktor penentu lahirnya media baru. Teknologi pula yang membuat salah satu bentuk media baru, media sosial, memiliki pengguna yang sangat banyak. Teknologi media sosial memungkinkan setiap orang saling terhubung. Mereka bisa mengemas dan mendistribusikan pesan dengan leluasa. Pada saat yang sama, publik di tempat lain bisa menerima pesan itu secara cepat dan utuh, untuk kemudian mengemas umpan balik dan mengirimkannya kembali. Pada 
titik ini, media sosial telah mentransformasi fungsi atau peran komunikator dan komunikan.

Di balik berbagai fitur baru yang ditawarkan, media sosial sendiri justru mengalami transformasi fungsi konstruksi. Keleluasaan dan keterhubungan yang diberikan kepada pengguna, justru mendegradasi otoritas media sosial itu sendiri. Independensi pengguna telah membuat media sosial hanya sebagai perantara atau penyampai pesan, bukan sebagai media yang memiliki fungsi konstruksi pesan seperti yang dimiliki oleh media konvensional. Gugurnya paradigma konstruktivis itu terjadi ketika pesan tidak akan mengalami perubahan ketika melalui proses transmisi.

Sisi positif dari transformasi fungsi konstruksi realitas itu adalah era digital telah mengembalikan fungsi objektivitas media, sehingga media hanya akan berperan sebagai penyalur pesan tanpa menyampuri atau bahkan mengubah makna pesan tersebut. Namun, transformasi ke arah positivistik ini juga perlu diwaspadai karena media berpotensi kehilangan fungsi pengawasan. Hanya menjadi penyalur pesan, media tidak lagi punya otoritas untuk mengemas pesan berdasarkan misi-misi mulia untuk memperjuangkan hak publik. Media sosial di satu sisi menawarkan transformasi keterhubungan, namun di sisi lain kehilangan fungsi pengawasan.

\section{DAFTAR RUJUKAN}

Bennett, L. (2004). Gatekeeping and pressgovernment relations: A multigated model. Dalam L. L. Kaid, Handbook of political communication research. London: Lawrence Erlbaum Associates.

Berger, P. L., \& Luckmann, T. (1966). The social construction of reality. A treatise in the sociology of knowledge. London: Pinguin Groups.

Eriyanto. (2001). Analisis wacana: pengantar analisis teks media. Yogyakarta: LKIS.

German, K. M. (2009). Dramatism and dramatistic pentad. Dalam S. W. Littlejohn, \& K. A. Foss, Encyclopedia of communication theory ( $\mathrm{p}$. 321). London: Sage Publications Inc.

Goffman, E. (1956). The presentation of self in everyday life. Edinburgh: Social Sciences Research Centre University of Edinburgh.

Kompas.com. (2013, Juli 5) Presiden SBY resmi luncurkan fan page Facebook. http://nasional. kompas.com/read/2013/07/05/2140528/ Presiden.SBY.Resmi.Luncurkan.Fan.Page. Facebook

McQuail, D. (2005). Mass communication theory. London: Sage Publications.

Newman, B. I., \& Perloff, R. M. (2004). Political marketing: theory, research, and applications. In L. Lee Kaid, Handbook of political communication research. London: Lawrence Erlbaum Associates.

Postman, N. (1993). Technopoly. New York: Vintage Books.

Sharma, D. C. (2007). Develpment journalism an introduction. Quezon City: Asian Center for Journalism Ateneo de Manila Univertisy.

Shoemaker, P. J., \& Reese, S. D. (1996). Mediating the message, theories of influence on mass media content. New York: Longman Publishers USA.

Thwaites, T., Lloyd, D., \& Mules, W. (2002). Introducing cultural and media studies, a semiotic approach. New York: Palgrave.

Weaver, D., McCombs, M., \& Shaw, D. L. (2004). Agenda-setting research: issues, attributes, and influences. In L. L. Kaid, Handbook of political communication research. London: Lawrence Erlbaum Associates. 